\title{
Karakteristik Personal, Perilaku Disfungsional Audit Dan Dampaknya Pada Kualitas Audit
}

Ahimsyah Wahyu Pratama ${ }^{1}$

${ }^{1}$ Universitas Pancasila, Jl. Raya Lenteng Agung, Jagakarsa, Jakarta Selatan 12640

I N F O A R T I K E L JEL Classification:

M42

\section{Keywords:}

audit quality,

dysfunctional audit behavior,

locus of control,

professional commitment, turnover intention
A $\quad$ B $S$ S T T R A $A$ C T

The purpose of this research is to obtain the empirical evidence of the influence of locus of control, professional commitment, and turnover intention, to the dysfunctional audit behavior and to its impact on the audit quality. The type of data used for this research is the primary data collected through questionnaires. The population used in this research is the auditors of The Audit Board of Republic of Indonesia (BPK) who holds the role as the Senior Team Leader and Junior Team Leader, with size of 758. The sampling method used is the purposive sampling technique by taking into account the specific characteristics according to the needs of the research with the sample size of 87 respondents. The method of data analysis used on this research is the SEM with variance structure approach, which is the Partial Least Squere (PLS). The result shows that the locus of control has negative correlation and has significant influence to the dysfunctional audit behavior. The professional commitment also has negative correlation but does not has significant influence to the dysfunctional audit behavior. On the contrary, the turnover intention has positive correlation and has significant influence to the dysfunctional audit behavior, while the dysfunctional audit behavior has negative correlation and has significant influence to the audit quality produced by auditors.

\section{A B S T T R A K}

Penelitian ini bertujuan untuk memperoleh bukti empiris pengaruh lokus kendali, komitmen profesi, dan turnover intention terhadap perilaku disfungsional audit serta dampaknya bagi kualitas audit. Jenis data yang digunakan dalam penelitian ini adalah data primer yang dikumpulkan melalui kuesioner. Populasi yang digunakan dalam penelitian ini adalah pegawai yang duduk dalam jabatan fungsional pemeriksa (JFP) di BPK yang memiliki peran sebagai Ketua Tim baik Ketua Tim Senior (KTS) maupun Ketua Tim Yunior (KTY) sebanyak 758. Penarikan sampel menggunakan teknik purposive sampling dengan mempertimbangkan karakteristik tertentu sesuai dengan kebutuhan penelitian sebanyak 87 responden. Metode analisis data pada penelitian ini menggunakan SEM dengan pendekatan structure varians yaitu Partial Least Squere (PLS). Hasil penelitian menunjukan bahwa lokus kendali berkorelasi negatif dan memiliki pengaruh yang signifikan terhadap perilaku disfungsional audit. Komitmen profesi berkorelasi negatif namun tidak memiliki pengaruh signifikan terhadap perilaku disfungsional audit. Turnover intention berkorelasi positif dan memiliki pengaruh yang signifikan terhadap perilaku disfungsional audit, serta perilaku disfungsional audit berkorelasi negatif dan berpengaruh signifikan terhadap kualitas audit yang dihasilkan pemeriksa BPK.

*Email Korespondensi: '1ahimsyah.wahyu@yahoo.com 


\section{Pendahuluan}

Dalam upaya mewujudkan pengelolaan keuangannegarayangbaik, terdapattuntutanuntuk mengedepankan nilai-nilai good governance. Nilai-nilai tersebut adalah transparansi, akuntabilitas, serta partisipasi masyarakat dalam proses pengelolaan keuangan negara serta nilai-nilai efektivitas dan efisiensi. Penerapan nilai-nilai good governance bukanlah suatu langkah yang mudah, hal ini disebabkan adanya beberapa persoalan dalam pengelolaan keuangan negara, terutama rendahnya transparansi dan akuntabilitas penggunaan keuangan pemerintah. Rendahnya transparansi dan akuntabilitas dalam pertanggungjawaban dan pengelolaan keuangan negara tergambar dalam hasil pemeriksaan Badan Pemeriksa Keuangan (BPK) yang terangkum dalam Ikhtisar Hasil Pemeriksaan Semester (IHPS) II BPK tahun 2014. Dari 651 objek pemeriksaan, ditemukan 7.950 temuan yang di dalamnya terdapat 2.482 permasalahan kelemahan SPI dan 7.789 ketidakpatuhan terhadap ketentuan perundang-undangan senilai Rp. 40,55 triliun. Dari permasalahan ketidakpatuhan tersebut, sebanyak 3.293 permasalahan berdampak pada pemulihan keuangan negara/ daerah/ perusahaan (berdampak finansial) senilai Rp 14,74 triliun.

Salah satu upaya konkrit mewujudkan transparansi dan akuntabilitas pengelolaan keuangan negara adalah melalui pemeriksaan atas pengelolaan dan pertanggungjawaban keuangan negara yang berkualitas. Pemeriksaan laporan keuangan bertujuan untuk menjamin kewajaran informasi keuangan yang disajikan dalam laporan keuangan, sedangkan dalam arti yang luas pemeriksaan keuangan negara bertujuan untuk menjawab tuntutan pengelolaan keuangan negara yang transparan dan akuntabel. Pemeriksaan keuangan juga dapat dijadikan pintu masuk untuk membongkar potensi ada atau tidaknya unsur pidana. Mengingat pentingnya sebuah pemeriksaan, dibutuhkan pihak eksternal di luar pemerintahan yang kuat dan mandiri untuk memeriksa laporan pertanggungjawaban pengelolaan keuangan negara, dan sesuai amanat Undang Undang Nomer 15 Tahun 2004 tentang Pemeriksaan Pengelolaan dan Tanggung Jawab Keuangan Negara Pasal 2 peran tersebut dilaksanakan oleh BPK.

Pada kenyataannya, pemeriksaan BPK banyak digugat dan diragukan kualitasnya oleh auditee. Pada kurun waktu 2009 hingga Februari 2015 saja, tercatat sudah 11 kali BPK digugat ke pengadilan perdata, 4 kali digugat ke pengadilan tata usaha negara, serta 4 kali mendapat somasi dengan objek gugatan LHP BPK, rekomendasi, dan perhitungan kerugian negara yang dihasilkan BPK. Banyaknya gugatan yang ditujukan terhadap audit BPK menunjukkan bahwa terdapat permasalahan dalam kualitas audit BPK, hal ini disebabkan karena BPK dinilai telah melakukan perilaku yang menyimpang dalam pelaksanaan pemeriksaan, antara lain: pemerolehan bukti yang kurang, pemrosesan yang kurang akurat dan kesalahan dari tahapan. Perilaku menyimpang dalam pemeriksaan tersebut dikenal sebagai perilaku disfungsional audit.

Penelitian yang dilakukan oleh Public Oversight Board (2010) yang menyatakan 85\% bentuk penyimpangan auditor yang terjadi adalah penyelesaian langkah-langkah audit yang terlalu dini tanpa melengkapi keseluruhan prosedur dan kira-kira $12,2 \%$ bentuk penyimpangan yang terjadi adalah melaporkan waktu audit dengan total waktu yang lebih pendek daripada waktu yang sebenarnya. Selebihnya bentuk penyimpangan yang terjadi adalah bukti-bukti yang dikumpulkan kurang mencukupi dan mengganti prosedur audit yang telah ditetapkan pada waktu pemeriksaan lapangan.

Menurut Jansen \& Glinow (1985) dalam Malone \& Roberts (1996), perilaku individu merupakan refleksi dari sisi personalitasnya sedangkan faktor situasional yang terjadi saat itu akan mendorong seseorang untuk membuat suatu keputusan. Literatur terdahulu mengidentifikasi faktor-faktor lingkungan (seperti tekanan waktu, model atau gaya pengawasan) dan faktor personal auditor (seperti: locus of control, organizational commitment, turnover intention, dan self rate performance) secara signifikan mempengaruhi perilaku disfungsional (Otley \& Pierce,1995). Tingkat perilaku disfungsional yang sangat 
mengganggu berhubungan dengan profesi auditing (Otley \& Pierce, 1995).

Dengan mengetahui variabel-variabel penyebab perilaku disfungsional audit dan dampaknya terhadap kualitas audit diharapkan dapat memberi masukan dalam meningkatkan kualitas audit sehingga respon kurang positif dari entitas terperiksa serta pemangku kepentingan dari laporan hasil pemeriksaan BPK dapat dicegah. Atas pertimbangan tersebut, maka peneliti ingin memperoleh bukti empiris dan menganalisis pengaruh lokus kendali; komitmen profesi dan turnover intention terhadap perilaku disfungsional audit dan dampaknya terhadap kualitas audit.

\section{Telaah Teori dan Pengembangan Hipotesis}

Welfare State dirintis pertama kali oleh Jerman dibawah Otto Von Bismarck sejak Tahun 1850-an. Otto mengemukakan prinsip dasar teori welfare state, yakni bahwa negara/pemerintah bertanggung jawab penuh untuk menyediakan semua kebutuhan rakyatnya dan tidak dapat dilimpahkan kepada siapapun (Abercrombie: 2000). Konsep negara kesejahteraan (welfare state) menempatkan peran negara dalam setiap aspek kehidupan rakyatnya demi terwujudnya kesejahteraan sosial bagi seluruh rakyat (Mustamin Dg. Matutu: 1972). Sehubungan dengan konsep negara kesejahteraan tersebut, maka negara mengemban 4 (empat) fungsi yakni negara sebagai pelayan, pengatur, pengusaha, dan wasit (W. Friedmann, 1971). Guna memastikan keempat fungsi tersebut berjalan dengan baik, maka diperlukan suatu lembaga audit yang bebas dan mandiri untuk melaksanakan pemeriksaan atas pengelolaan dan tanggung jawab keuangan negara yaitu BPK.

\section{Pengaruh Lokus Kendali Terhadap Perilaku Disfungsional Audit}

Lokus kendali adalah sebuah konsep yang dikembangkan oleh Rotter (1966) dalam Donelly, et.al (2003) dan sudah digunakan secara meluas dalam berbagai riset mengenai perilaku disfungsional dalam sebuah lembaga audit.
Hellriegel dan Slocum (2004: 56) menyatakan bahwa individu dengan lokus kendali internal yang tinggi terbukti lebih berperilaku etis ketika membuat keputusan organisasional daripada yang dilakukan oleh individu dengan lokus kendali eksternal yang tinggi.

Mudrack (1989) dalam Donelly et al (2003) menyimpulkan bahwa penggunaan manipulasi, penipuan, dan taktik menjilat atau mengambil muka dapat menggambarkan suatu usaha dari lokus kendali eksternal untuk mempertahankan pengaruh mereka terhadap lingkungan yang kurang ramah dan memberikan kepada mereka sebuah pendekatan berorientasi internal seperti kerja keras. Penelitian Donnely et al (2003) serta Gable dan De angello (1994) menunjukkan bahwa terdapat korelasi positif yang kuat antara lokus kendali eksternal dengan keinginan untuk melakukan kecurangan dan manipulasi untuk mencapai tujuan mereka.

H1 : Lokus kendali berpengaruh signifikan terhadap perilaku disfungsional audit.

\section{Pengaruh Komitmen Profesi terhadap Perilaku Disfungsional Audit}

Komitmen auditor terhadap profesinya merupakan faktor penting yang berpengaruh terhadap perilaku auditor dalam melaksanakan tugas audit (Shaub et al, 1993 dalam Adanan Silaban, 2011). Menurut Shaub et al (1993) komitmen profesi merupakan faktor penting yang mempengaruhi perilaku auditor dalam pengambilan keputusan etis. Selanjutnya, mereka mengatakan perbedaan dalam perilaku etis yang dilakukan auditor terhadap profesinya. Auditor yang memiliki komitmen kuatakan berusahauntuk menjaga nilai-nilai profesi dengan menghindari perilaku yang dapat merusak profesi seperti perilaku disfungsional audit (Adanan Silaban, 2011:5). Hasil penelitian Jeffrey dan Weatherholt (1996), Malone dan Robert (1996); Otley dan Pierce (1998), Kaplan dan Whiteecotton (2001). menunjukkan adanya hubungan antara variabel komitmen profesi dengan perilaku auditor.

H2 : Komitmen profesi berpengaruh signifikan terhadap perilaku disfungsional audit. 


\section{Pengaruh Turnover Intention Terhadap Perilaku Disfungsional Audit}

Turnover intention merupakan keinginan seseorang untuk keluar organisasi, yaitu evaluasi mengenai posisi seseorang saat ini berkenaan dengan ketidakpuasan dapat memicu seseorang untuk keluar dan mencari pekerjaan lain. Penelitian Irawati, dkk (2005) yang menemukan bahwa terdapat hubungan positif antara keinginan untuk berhenti bekerja dengan penerimaan penyimpangan perilaku audit. Penelitian Tyas dan Kiryanto (2015) menunjukkan bahwa variabel independen turnover intention berhubungan dengan penerimaan perilaku disfungsional audit.

Malone \& Roberts (1996) menyatakan bahwa para auditor yang dengan tujuan atau bermaksud untuk meninggalkan perusahaan bisa jadi lebih mau untuk ikut turut serta dalam perilaku disfungsional audit dengan tujuan menurunkan atau mengurangi kekhawatiran atau rasa takut akan kemungkinan penghentian atau pemecatan jika perilaku mereka tersebut dideteksi.

H3 : Turnover intention berpengaruh signifikan terhadap perilaku disfungsional audit.

\section{Pengaruh Perilaku Disfungsional Audit terhadap Kualitas Audit}

Beberapa hasil penelitian sebelumnya menunjukan bahwa secara umum perilaku disfungsional audit berpengaruh negatif terhadap kualitas audit (Rasuli, 2008; Donnely, et.al, 2003). Penelitian Fatimah (2012) mendukung hal ini dan berpendapat kualitas audit akan dikorbankan jika auditortidakmenjalankanbeberapaproseduraudit. Selanjutnya, perilaku disfungsional audit akan memberikan ancaman langsung pada realibilitas dari sebuah proses audit serta akan memberikan dampak yang kurang baik di masa yang akan datang. Penelitian terdahulu menunjukkan bahwa perilaku disfungsional audit bisa mempunyai pengaruh langsung dan tidak langsung terhadap kualitas audit. Perilaku yang mempunyai pengaruh langsung termasuk premature sign-off, pemerolehan bukti yang kurang (Otley \& Pierce, 1995; Donelly et al. 2003), pemrosesan yang kurang akurat (Mc Danield, 1990) dan kesalahan dari tahapan audit (Margheim \& Pany, 1986), altering/replacing of audit procedure (Donelly, et al. 2003) dan perilaku audit yang mempunyai pengaruh tidak langsung terhadap kualitas audit adalah under reporting of time (Donelly et al. 2003). Perilaku disfungsional audit diyakini akan memberikan yang kurang baik bagi kualitas audit (Kiryanto, 2015). Perilaku disfungsional audit berhubungan dengan penurunan kualitas audit (Public Oversight Board, 2000 dalam Donelly et al. 2003).

H4 : Perilaku disfungsional audit berpengaruh signifikan terhadap kualitas audit.

\section{Metode}

Metode yang digunakan dalam penelitian ini adalah metode penelitian kuantitatif, yaitu metode penelitian yang berlandaskan pada filsafat positivisme, digunakan untuk meneliti pada populasi atau sampel tertentu, teknik pengambilan sampel pada umumnya dilakukan secara random, pengumpulan data menggunakan instrumen penelitian berupa kuesioner, analisis data bersifat kuantitatif/statistik dengan tujuan untuk menguji hipoteisi yang telah ditetapkan (Sugiyono, 2012: 13). Dalam penelitian ini sampel diambil secara purposive sampling, teknik penentuan sampel dengan pertimbangan tertentu sehingga diperoleh 87 responden.

Hipotesis penelitian dibuktikan dengan perhitungan menggunakan SEM dengan Partial Least Square. Alasan penulis menggunakan teknik ini adalah karena dalam penelitian ini melibatkan variabel-variabel laten dengan ukuran sampel yang relatif kecil. Dalam PLS tidak dibutuhkan ukuran sampel yang besar tidak seperti SEM berbasis kovarian (Sarwono, 2015).

\section{Hasil Penelitian dan Pembahasan}

Penelitian ini mengkaji kualitas audit, perilaku disfungsional audit, lokus kendali, komitmen profesi dan turnover intention. Deskripsi variable penelitian sebagaimana tampak pada tabel berikut. Hasil perhitungan grand mean untuk skor tanggapan responden mengenai kualitas audit sebesar 4,570, perilaku 
disfungsional audit sebesar 4,516, lokus kendali sebesar 4,318, komitmen profesi sebesar 4,374, dan turnover intention sebesar 4,402, seluruh variabel memiliki grand mean yang berada pada kuartil $4\left(\mathrm{Q}_{4}\right)$ atau interval $4-5$ yang masuk dalam kategori baik. (tabel.1)

Pengujian hipotesis meliputi duatahapan, uji outer model, dan uji inner model. Penilaian outer model (model pengukuran) dilakukan dengan melihat reliabilitas dan validitas variabel penelitian.Ukuran yang digunakan dalam menilai reliabilitas dan validitas variabel (model pengukuran) yaitu convergent validity, discriminant validity dan composite reliability. (tabel.2).
Hasil pada perhitungan menunjukkan outer loading untuk masing-masing variabel manifes (indikator) dari variabel laten pada penelitian ini lebih dari 0,5 maka ini membuktikan bahwa indikator yang digunakan untuk mengukur variabel laten dalam penelitian ini telah memenuhi convergent validity. (tabel.3)

Hasil korelasi antar konstruk dan nilai akar AVE pada tabel tersebut di atas menunjukkan bahwa nilai akar AVE untuk variabel turnover intention, variabel lokus kendali, variabel komitmen profesi, variabel perilaku disfungsional audit dan variabel kualitas audit lebih besar dari nilai korelasi antar konstruknya. Secara umum hasil ini menunjukkan bahwa discriminant validity laten variabel sudah tinggi. (tabel.4)

Tabel 1. Skor Penilaian Responden

\begin{tabular}{lcccc}
\hline \multicolumn{1}{c}{ Variabel } & Skor Aktual & Skor Ideal & Grand Mean & $\%$ \\
\hline Kualitas audit (Y2) & 2783 & 3045 & 4,570 & $91,4 \%$ \\
Perilaku disf. audit (Y1) & 3929 & 4350 & 4,516 & $90,3 \%$ \\
Lokus kendali (X1) & 3005 & 3480 & 4,318 & $86,4 \%$ \\
Komitmen profesi (X2) & 6850 & 7830 & 4,374 & $87,5 \%$ \\
Turnover intention (X3) & 1915 & 2175 & 4,402 & $88,0 \%$ \\
\hline
\end{tabular}

Tabel 2. Validitas Konvergen

\begin{tabular}{lccc}
\hline Variabel & Rentang Outer Loading & Kriteria & Keterangan \\
\hline Kualitas audit (Y2) & $0,689-0,899$ & 0,5 & valid \\
Perilaku disf. audit (Y1) & $0,838-0,885$ & 0,5 & valid \\
Lokus kendali (X1) & $0,702-0,960$ & 0,5 & valid \\
Komitmen profesi (X2) & $0,890-0,972$ & 0,5 & valid \\
Turnover intention (X3) & $0,863-0,948$ & 0,5 & valid \\
\hline
\end{tabular}

Tabel 3. Nilai Akar AVE Untuk Menilai Validitas Diskriminan

\begin{tabular}{lccccc}
\hline & $\begin{array}{c}\text { Komitmen } \\
\text { Profesi (X2) }\end{array}$ & $\begin{array}{c}\text { Kualitas } \\
\text { Audit (Y2) }\end{array}$ & $\begin{array}{c}\text { Lokus } \\
\text { Kendali } \\
(\mathrm{X} 1)\end{array}$ & $\begin{array}{c}\text { Perilaku } \\
\text { Disfungsional } \\
\text { Audit (Y1) }\end{array}$ & $\begin{array}{c}\text { Turnover } \\
\text { Intention } \\
(\mathrm{X} 3)\end{array}$ \\
\hline Komitmen Profesi (X2) & 0,930 & 0,573 & $-0,110$ & $-0,455$ & $-0,388$ \\
Kualitas Audit (Y2) & 0,573 & 0,863 & $-0,066$ & $-0,457$ & $-0,382$ \\
Lokus Kendali (X1) & $-0,110$ & $-0,066$ & 0,801 & 0,336 & 0,631 \\
Perilaku disf. audit (Y1) & $-0,455$ & $-0,457$ & 0,336 & 0,806 & 0,757 \\
Turnover Intention (X3) & $-0,388$ & $-0,382$ & 0,631 & 0,757 & 0,900 \\
\hline
\end{tabular}


Tabel 4. Nilai Composite Reliability dan Cronbachs Alpha

\begin{tabular}{lccc}
\hline Variabel & $\begin{array}{c}\text { Composite } \\
\text { Reliability }\end{array}$ & R Square & $\begin{array}{c}\text { Cronbachs } \\
\text { Alpha }\end{array}$ \\
\hline Lokus kendali (X1) & 0,934 & & \\
Komitmen Profesi (X2) & 0,991 & & \\
Turnover intention (X3) & 0,955 & 0,626 & 0,942 \\
Perilaku disf audit (Y1) & 0,949 & 0,209 & 0,944 \\
Kualitas audit (Y2) & 0,954 & & \\
\hline
\end{tabular}

Berdasarkan tabel 4 dapat disimpulkan bahwa semuakonstruk memenuhi kriteria reliabel. Hal ini ditunjukkan dengan nilai composite reliability di atas 0,70 sebagaimana kriteria yang direkomendasikan.

Pengujian model struktural (inner model) dilakukan dengan menggunakan $R$-square untuk konstruk dependen dan uji t (signifikansi) dari koefisien parameter jalur struktural. Hasil model struktural menunjukan bahwa ketiga variabel eksogen yakni Lokus Kendali, Komitmen Profesi, dan Turnover Intention dapat menjelaskan variabel endogen perilaku disfungsional audit sebesar 63\% (R-square sebesar 0.626) sedangkan sisanya yakni $37 \%$ dipengaruhi oleh variabel lain di luar variabel eksogen yang digunakan dalam penelitian ini. Sedangkan untuk model berikutnya, menunjukkan bahwa Perilaku Disfungsional Audit dapat menjelaskan variabel endogen Kualitas Audit sebesar 21\% (R-square sebesar 0.209), sedangkan sisanya dipengaruhi oleh variabel lainnya di luar variabel yang diteliti.

Hasil penelitian menerima hipotesis lokus kendali berpengaruh signifikan terhadap perilaku disfungsional audit pada pemeriksa BPK. Hubungan antara lokus kendali dengan perilaku disfungsional audit adalah sebesar -0,199, hal ini menunjukkan bahwa kedua variabel tersebut berkorelasi negatif tetapi lemah yang artinya semakin tinggi lokus kendali maka akan semakin rendah perilaku disfungsional audit. Hasil penelitian ini sejalan dengan fenomena yang telah diuraikan dalam pendahuluan dan hipotesis penelitian, yakni masalah suap yang menjerat pemeriksa BPK menunjukkan lemahnya lokus kendali internal dari auditor tersebut.

Hasil penelitian menolak hipotesis komitmen profesi berpengaruh signifikan terhadap perilaku disfungsional audit. Dengan kata lain komitmen profesi memiliki pengaruh terhadap perilaku disfungsional audit namun tidak signifikan. Hubungan antara komitmen profesi dengan perilaku disfungsional audit adalah sebesar-0,157, hal ini menunjukkan bahwa kedua variabel tersebut berkorelasi negatif tetapi lemah yang artinya semakin tinggi komitmen profesi maka perilaku disfungsional audit akan semakin rendah. Hasil penelitian ini sejalan dengan fenomena yang telah diuraikan dalam pendahuluan dan hipotesis penelitian, yakni kecenderungan pemeriksa BPK untuk keluar dari profesi sebagai pemeriksa BPK. Penyebab dari adanya pengaruh yang tidak signifikan dari komitmen profesi terhadap perilaku disfungsional audit disebabkan oleh kurangnya kekhawatiran dari pemeriksa BPK atas kemungkinan hilangnya pendapatan. Penulis mengamati bahwa pemeriksa BPK yang beralih profesi umumnya mendapat pekerjaan baru dengan penghasilan yang lebih tinggi. Selain itu pekerjaan baru tersebut masih berhubungan dengan bidang akuntansi atau audit, sehingga tidak sepenuhnya dapat dianggap sebagai "pergantian profesi" melainkan hanya perpindahan instansi/ perusahaan.

Hasil penelitian menerima hipotesis yaitu turnover intention berpengaruh signifikan terhadap perilaku disfungsional audit. Hubungan antara turnover intention dengan perilaku disfungsional audit adalah sebesar 0,821, hal ini menunjukkan bahwa kedua variabel tersebut berkorelasi positif dan sangat kuat yang artinya 
bahwa semakin tinggi turnover intention maka perilaku disfungsional audit akan tinggi. Hasil penelitian ini sejalan dengan fenomena yang telah diuraikan dalam pendahuluan dan hipotesis penelitian, yakni kecenderungan yang meningkat atas jumlah pegawai yang berhenti di periode tahun 2010-2015.

Hasil penelitian menerima hipotesis perilaku disfungsional audit berpengaruh signifikan terhadap kualitas audit pemeriksa BPK. Hubungan antara perilaku disfungsional audit dengan kualitas audit adalah sebesar -0,457 hal ini menunjukkan bahwa kedua variabel tersebut berkorelasi negatif tingkat sedang yang artinya semakin tinggi perilaku disfungsional audit maka kualitas audit akan semakin rendah. Hasil penelitian ini sejalan dengan fenomena yang telah diuraikan dalam pendahuluan dan hipotesis penelitian, yakni pemeriksaan BPK banyak digugat dan diragukan kualitasnya oleh auditee. Materi gugatan menyatakan bahwa BPK dianggap telah melakukan pelanggaran prosedur saat melakukan penghitungan.

\section{Simpulan, Keterbatasan, dan Implikasi Hasil Penelitian}

Berdasarkan pengujian empiris dan analisis pembahasan dapat disumpulkan halhal sebagai berikut. Lokus kendali berpengaruh signifikan terhadap perilaku disfungsional audit. Hubungan antara lokus kendali dengan perilaku disfungsional audit negatif tetapi lemah, artinya apabila lokus kendali dilakukan secara konsisten dan terus menerus maka perilaku disfungsional audit akan rendah.. Masalah yang dihadapi berkaitan dengan indikator faktor usaha, yang berarti pemeriksa BPK yang memiliki keyakinan bahwa keberhasilan mereka ditentukan oleh usaha yang sungguh-sungguh akan cenderung menghindari perilaku disfungsional audit.

Komitmen profesi tidak berpengaruh signifikan terhadap perilaku disfungsional audit. Hubungan komitmen profesi dengan perilaku disfungsional audit adalah negatif tetapi lemah, artinya apabila komitmen profesi tidak dimiliki pemeriksa BPK maka perilaku disfungsional audit akan tinggi. Masalah yang dihadapi berkiatan dengan indikator kehilangan pendapatan, ini berarti pemeriksa BPK yang merasa khawatir bahwa jika beralih profesi menimbulkan konsekuensi kehilangan pendapatan akan cenderung menghindari perilaku disfungsional audit.

Turnoverintention berpengaruh signifikan terhadap perilaku disfungsional audit. Hubungan antara turnover intention dengan perilaku disfungsional audit positif dan kuat, yang artinya apabila turnover intention tinggi maka perilaku disfungsional audit akan tinggi. Masalah yang dihadapi berkaitan dengan indikator mencari pekerjaan lain, artinya pemeriksa BPK yang berkeinginan untuk beralih pekerjaan akan cenderung melakukan perilaku disfungsional audit.

Perilaku disfungsional audit berpengaruh signifikan terhadap kualitas audit. Hubungan antara pengaruh perilaku disfungsional audit dengan kualitas audit negatif tingkat sedang, artinya apabila perilaku disfungsional audit meningkat maka Kualitas Audit akan rendah. Masalah perilaku disfungsional audit terbesar ditunjukkan oleh indikator penghentian prematur prosedur audit, ini berarti pemeriksa BPK yang sering menghentikan prosedur audit di tengah pemeriksaan akan menghasilkan ouput pemeriksaan yang rendah.

Dalam penelitian ini masih terdapat keterbatasan-keterbatasan sebagai berikut:

1. Teknik penarikan sampel dalam penelitian ini menggunakan purposive sampling, yakni memilih sampel berdasarkan karakteristik tertentu. Pada penelitian ini menggunakan sampel sebanyak 87 responden yang merupakan pemeriksa BPK dengan peran KTY dan KTS yang bertugas di 2 satuan kerja saja. Mengingat keterbatasan sampel tersebut maka hasil penelitian ini kurang dapat digeneralisir untuk seluruh pemeriksa BPK.

2. Adanya faktor-faktor lain yang berpengaruh terhadap perilaku disfungsional audit seperti etika dan tingkat kinerja pegawai serta beberapa faktor yang berpengaruh signifikan 
terhadap kualitas audit diantaranya: gender, kompetensi, dan pengalaman yang tidak ikut diteliti.

3. Penelitian ini belum melakukan pengujian untuk pengaruh langsung variabel eksogen terhadap kualitas audit sehingga hasil penelitian perlu diperdalam.

Saran operasional yang dapat diberikan adalah, BPK sebaiknya membuat sistem remunerasi (pendapatan) yang menarik, karena menurut hasil penelitian faktor kekhawatiran kehilangan pendapatan memberikan sumbangan pengaruh terbesar terhadap komitmen profesi dari pemeriksa BPK. BPK dalam hal ini Inspektorat Utama, meningkatkan review atas laporan hasil pemeriksaan, hal ini dilakukan untuk menekan terjadinya perilaku disfungsional audit khususnya terkait penghentian prematur prosedur audit yang mempengaruhi kualitas audit.

Pada dunia akademis, hasil penelitian ini diharapkan dapat meningkatkan pengembangan ilmu akuntansi khususnya audit sektor publik penelitian ini telah membuktikan bahwa karakter personal yang meliputi variabel: lokus kendali, komitmen profesi, dan turnover intention berpengaruh terhadap kualitas audit melalui perilaku disfungsional audit. Dengan demikian berdasarkan hasil pengujian hipotesis yang telah dilakukan dapat dikonfirmasi bahwa teori dan konsep yang diteliti dalam penelitian ini masih tetap berlaku saat ini, dan dapat dilanjutkan lagi dengan penelitian-penelitian selanjutnya untuk membangun teori yang bermanfaat dalam pengembangan ilmu. Bagi peneliti selanjutnya, pada penelitian inibelum mengungkapkan seluruh variabel-variabel yang dapat mempengaruhi perilaku disfungsional audit dan kualitas audit, maka dalam rangka penelitian lanjutan diharapkan peneliti selanjutnya meneliti variabel-variabel lain yang mempengaruhi perilaku disfungsional audit seperti motivasi dan tingkat kinerja pegawai serta beberapa faktor yang berpengaruh signifikan terhadap kualitas audit diantaranya: gender, kompetensi, dan pengalaman yang tidak diteliti oleh penulis. Selain itu, disarankan juga agar menambahkan jumlah responden dan cakupan penelitian agar didapatkan gambaran yang lebih objektif dan menambah kemungkinan generalisasi hasil penelitian, serta menguji dan menganalisis pengaruh langsung dari variabel eksogen terhadap kualitas audit.

\section{Daftar Rujukan}

Abercrombie, et al, 2010. Kamus Sosiologi.

Pustaka Pelajar, Yogyakarta.

DeAngelo, LE, 1981, Auditor Size and Audit Quality. Journal of Accounting and Economics December 1981.

Deis, D. R. dan Gary A. Giroux. 1992. Determinants of Audit Quality in the Public Sector. The Accounting Review

Donnelly, et.al, 2003. Attitudes Toward Dysfunctional Audit Behavior: The Effects Of Locus Of Control, Organizational Commitment, and Position. The Journal of Applied Busisness Reserach, Volume 19, No 1,2003

Fatimah, Annisa, 2012. Karakteristik Personal Auditor Sebagai Anteseden Perilaku Disfungsional Auditor dan Pengaruhnya Terhadap Kualitas Audit. Jurnal Akuntansi dan Manajemen, Volume 1, Nomer 1, April, 2012

Hellriegel, Don dan Slocum, John W, 2004. Organization Behavior, $10^{\text {th }}$ edition. Thomson Learning, Ohio.

Irawati, Yuke, dkk. 2005. Hubungan Karakteristik

Personal Auditor Terhadap Tingkat Penerimaan Penyimpangan Perilaku Audit. Jurnal Simposium Nasional Akuntansi VIII, Solo, 2005

Kiryanto dan Tyas, Ayu Ning, 2015. Antaseden dan Konsekuensi Perilaku Disfungsional Auditor. CBAM, UNISSULA, Vol.2 No.1, Mei 2015.

Meyer, J. P., \& Allen, N. J, 1991, A Three-

Component Conceptualization of

Organizational Commitmrnt Human

Resource Management Review.

Meyer, J. P., \& Allen, N. J, 1997, Commitment

in the Worplace Theory Research and Application. Sage Publications, California. Rotter J.B, 1966. Genaralized Expectancies 
for Internal Versus External Control of Reinforcement. Pshycologycal Monographs, 80 Whole No. 69

Sarwono, J dan Narimawati, U, 2015. Membuat Skripsi, Tesis dan Disertasi dengan PLSSEM. Penerbit Andi, Yogyakarta.

Sarwono, S.W, 1999. Psikologi Sosial. Balai

Pustaka, Jakarta.

Sekaran, U, 2006. Research Method for Business:

Metodologi Penelitian Untuk Bisnis. Salemba Empat, Jakarta.

Setiawan, Ghozali, Aries, 2006. Akuntansi

Keperilakuan Konsep dan Kajian Empiris

Perilaku Akuntan. Badan Penerbit

Universitas Diponegoro, Semarang.

Shaub, et.al, 1993. The Effects of Auditor Ethical Orientation on Commitment and Ethical Sensitivity. Behavioral Research in Accounting Vol 5: 149-165

Silaban, Adanan, 2011. Perilaku Disfungsional Auditor dalam Pelaksanaan Program Audit. Journal of Accounting and Auditing Volume 8, Nomer 1, Tahun 2011

Sugiyono, 2012. Metode Penelitian Bisnis. Alfabeta, Bandung. 